\title{
The genus Lycoderides Sakakibara, stat. nov., its composition and descriptions of new species (Hemiptera, Membracidae, Stegaspidinae)
}

\begin{abstract}
Albino M. Sakakibara ${ }^{1}$
'Departamento de Zoologia, Universidade Federal do Paraná, Caixa Postal 19020, 81531-980 Curitiba-PR Brasil. amsakakibara@pq.cnpq.br

ABSTRACT. The genus Lycoderides Sakakibara, stat. nov., its composition and descriptions of new species (Hemiptera, Membracidae, Stegaspidinae).The subgenus Lycoderes (Lycoderides) Sakakibara, 1972 is raised to the genus category - Lycoderides stat. nov. - and it now includes: Lycoderides amazonicus (Sakakibara, 1991), comb. nov., Lycoderides brevilobus (Sakakibara, 1972), comb. nov., Lycoderides burmeisteri (Fairmaire, 1846), comb. nov., Lycoderides cultratus (Sakakibara, 1991), comb. nov., Lycoderides fernandezi (Strümpel, 1988), comb. nov., Lycoderides fuscus (Amyot \& Serville, 1843), comb. nov., Lycoderides gradatus (Sakakibara, 1972), comb. nov., Lycoderides hippocampus (Fabricius, 1803), comb. nov., Lycoderides luteus (Funkhouser, 1940), comb. nov., Lycoderides marginalis (Walker, 1851), comb. nov., Lycoderides nathanieli (Cryan, 1999), comb. nov., Lycoderides obtusus (Sakakibara, 1991), comb. nov., Lycoderides pennyi (Sakakibara, 1991), comb. nov., Lycoderides phasianus (Fowler, 1896), comb. nov. (= Enchenopa minamen Buckton, 1901, syn. nov.), Lycoderides protensus (Sakakibara, 1991), comb. nov., Lycoderides serraticornis (Fowler, 1896), comb. nov., and Lycoderides strumpeli (Sakakibara, 1991), comb. nov. The following new species are described: Lycoderides abditus, sp. nov., Lycoderides brulei, sp. nov. (both from French Guiana), Lycoderides capixaba, sp. nov. (from Brazil, Espírito Santo), Lycoderides cavichiolii, sp. nov. (from Brazil, Rio de Janeiro), Lycoderides meloi, sp. nov. (from Brazil, Bahia), and Lycoderides oliviae, sp. nov. (from Brazil, Minas Gerais). Other nomenclatural change: Stegaspis bracteata (Fabricius, 1787) = Lycoderes capitata Buckton, 1903, syn. nov. New records of geographical distribution and a key to the species are provided.
\end{abstract}

KEYWORDS. Auchenorrhyncha; Insecta; Stegaspidini; taxonomy; treehoppers.

Sakakibara (1972) divided the genus Lycoderes Germar, 1835 in two subgenera: Lycoderes (Lycoderes) s. str. and Lycoderes (Lycoderides). These two groups were separated by the different patterns of forewing venation. The subgenus L. (Lycoderes) was characterized by having "tegmina with apical cells normally disposed; fourth apical cell quadrangular or trapezoidal, or when petiolate not transversely disposed"; and the subgenus $L$. (Lycoderides) as "tegmina with apical cells obliquely disposed; fourth apical cell distinctly petiolate, triangular, narrow and transversely disposed, parallel to apical margin". Five species were placed in this subgenus: L. (Lycoderides) hippocampus (Fabricius, 1803), L. (Lycoderides) burmeisteri Fairmaire, 1846, L. (Lycoderides) fuscus Amyot \& Serville, 1843, L. (Lycoderides) gradatus Sakakibara, 1972, and L. (Lycoderides) brevilobus Sakakibara, 1972. In that revisional work, due to lack of material, five species were simply listed without subgeneric placement: Lycoderes phasianus Fowler, 1896, Lycoderes serraticornis Fowler, 1896, Lycoderes minamen (Buckton, 1901), Lycoderes capitatus Buckton, 1903, and Lycoderes luteus Funkhouser, 1940.

Strümpel (in Strümpel \& Strümpel 1988), described, among other treehoppers from Venezuela, two species: Lycoderes fernandezi and Lycoderes viridis. The existing subgenera were not considered.

Sakakibara (1991), in a paper dealing with the genera Stegaspis Germar, 1835 and Lycoderes Germar, 1835, de- scribed six species belonging to the subgenus $L$. (Lycoderides): L. strumpeli, L. pennyi, L. amazonica [sic], L. cultrata [sic], L. obtusa [sic], L. protensa [sic], and L. arguta [sic]. He also included in the same group, L. marginalis (Walker, 1851). On the other hand, Lycoderes viridis Strümpel, 1988 was transferred to Stegaspis Germar, 1835.

McKamey (1998) catalogued in the subgenus $L$. (Lycoderides), 12 species; and furthermore, in Lycoderes, without subgeneric placement, he listed six species: $L$. capitatus Buckton, 1903, L. fernandezi Strümpel, 1988, L. luteus Funkhouser, 1940, L. minamen (Buckton, 1901), L. phasianus Fowler, 1896, and L. serraticornis Fowler, 1896.

Cryan \& Deitz (1999) revised the tribe Stegaspidini, redescribing the genera Lycoderes Germar, Oeda Amyot \& Serville, and Stegaspis Germar. Those species of Lycoderes, without subgeneric placement (McKamey 1998), were assigned to the respective subgenera. A new species was also described, $L$. (Lycoderides) nathanieli Cryan, and a key to species of Lycoderes was presented.

In this paper, the subgenus $L$. (Lycoderides) is elevated to the genus category. In addition, Lycoderes capitatus Buckton, 1903 syn. nov. is transferred into Stegaspis Germar, as junior synonym of Stegaspis bracteata (Fabricius, 1787and Lycoderes minamen (Buckton, 1901) is considered as a new synonym of Lycoderides phasianus (Fowler, 1896) comb. nov. Furthermore, new geographical distribution records and a key to species are given. Material studied are deposited in 
the following collections: Coleção de Entomologia Pe. Jesus Santiago Moure, Departamento de Zoologia, Universidade Federal do Paraná (DZUP, Curitiba, Brazil), and Museum National d'Histoire Naturelle (MNHN, Paris, France).

\section{Lycoderides Sakakibara, 1972, stat. nov.}

Lycoderes (Lycoderides) Sakakibara, 1972: 95; McKamey, 1998: 307; Cryan \& Deitz, 1999: 768.

Type species: Centrotus hippocampus Fabricius, 1803, by original designation.

This genus is very close to Lycoderes Germar, and can be distinguished by the following characters: forewings with external apical angle more or less acute, tip rounded; one discoidal and five apical cells, these obliquely disposed (more often the fourth and the fifth together occupying whole apical margin); fourth apical cell (cell $\mathrm{M}_{1+2}$ ) transverse, triangular, usually petiolate, narrow and parallel to apical margin; third and fifth apical cells contiguous having the petiole of the fourth apical cell as common side or, in other words, with $r-m$ crossvein located basad to fork of vein $\mathrm{M}$; sometimes the petiole is absent, when $r-m$ is at the fork of $\mathrm{M}$.

The shape of the pronotum varies considerably; anterior process well developed, porrect, obliquely produced anteriorly, or short and almost vertical; suprahumeral horns (apical lobes) much reduced like small triangular lobes at apex or preapically, or well developed, slender or inflated, contiguous or divergent; posterior process slender, subcylindrical or slightly dilated, tectiform, with sharp dorsal carina running from top of anterior process to acute apex, this never surpassing internal angle of forewings, its base usually remote from scutellum, forming a distinct arch above it or, in some cases, very close, almost touching each other, but clearly visible from the side. On the other hand, in Lycoderides serraticornis (Fowler), Lycoderides fernandezi (Strümpel, 1988), and Lycoderides abditus sp. nov., the scutellum is completely covered by the posterior process, not visible at all.

\section{Key to species of Lycoderides}

1. Forewings entirely opaque (Fig. 4), densely pigmented, or with apical half translucent (Fig. 17),yellow or brownish ... 2

1 '. Forewings partially hyaline, colorless (Figs. 2, 3), sometimes speckled with dark brown (Figs. 12, 13), or transparent-amber (Fig. 28)

2. Scutellum concealed, not visible even laterally (Figs. 5, 17)

2'. Scutellum exposed, with posterior process very close to it (Figs. 1, 4)

3. General color yellowish brown (Figs. 5, 17)

3'. General color dark brown (Fig. 14) Lycoderides phasianus (Fowler, 1896)

4. Anterior pronotal process longer than posterior process (Fig. 5) ........... Lycoderides fernandezi (Strümpel, 1988)

4'. Anterior pronotal process shorter than posterior process (Fig. 17) ........ Lycoderides strumpeli (Sakakibara, 1991)
5. Anterior pronotal process subcylindrical (Fig. 1), in frontal view capitate, with suprahumeral horns short and horizontally disposed, median carina between them elevated ........ Lycoderides amazonicus (Sakakibara, 1991)

5'. Anterior pronotal process blade-shaped (Fig. 4), in frontal view compressed laterally and acute apically, with suprahumeral horns much reduced, forming only a carina on each side extending downwards parallel to anterior margin and evanescent near metopidium

Lycoderides cultratus (Sakakibara, 1991)

6. Forewings transparent-amber (Fig. 28); suprahumeral horns disposed in $\mathrm{V}$, each one about as long as width of head (Fig. 29), and posterior process distinctly falcate ..

Lycoderides cavichiolii, sp. nov.

6'. Different from above ................................................ 7

7. Forewings speckled on hyaline area ........................... 8

7'. Forewings not speckled ............................................ 11

8. Scutellum visible laterally .......................................... 9

8'. Scutellum concealed, not visible (Figs. 16, 18) ......... 10

9. Female: anterior process porrect, twice as long as broad at base, inclined anteriorly; suprahumeral horns small, preapically disposed; posterior process distinct, parallelsided, abruptly acute distally (Fig. 12). Male: anterior process continuous to posterior process forming together a foliaceous pronotum, sligthtly inclined posteriorly (Fig. 13); posterior process with same color as anterior process Lycoderides pennyi (Sakakibara, 1991)

9'. Female unknown. Male: anterior process continuous to posterior process forming together a foliaceous pronotum; anterior process almost vertical above metopidium, slightly inclined anteriorly; posterior process with basal 2/3 greenish yellow (Fig. 26) ......... Lycoderides capixaba, sp. nov.

10. Anterior process obliquely projected anteriorly, about four times longer than wide at base (Fig. 16)

Lycoderides serraticornis (Fowler, 1896)

$10^{\prime}$. Anterior process obsolete, just angled above metopidium (Fig. 18) ............................. Lycoderides abditus, sp. nov.

11. Scutellum visible laterally (base of posterior process close to scutellum) (Figs. 2, 8) ......................................... 19

11'.Scutellum free (base of posterior process remote from scutellum) (Figs. 3, 34)

12. Suprahumeral horns extending anteriorly from pronotum, curving in towards midline .

Lycoderides nathanieli (Cryan, 1999)

12'. Suprahumeral horns not as above..... 13

13.Suprahumeral horns well developed (about as long as width of head) contiguous Figs. 3, 33), or V-shaped each one triangular, wide at base or inflated (Figs. 23, 35) 14

13'. Suprahumeral horns short, usually as subapical triangular lobes, or much reduced (Figs. 9, 10) .................... 21

14. Suprahumeral horns elongate, contiguous, almost touching each other at mid internal margins and slightly divergent apically (Figs. 3, 33) ................................... 15 
14'. Suprahumeral horns short, divergent, V-shaped, or sometimes greatly inflated

15. Suprahumeral horns with borders sharp, distinctly carinate; posterior process straight; forewings opaque, only a small triangular hyaline area at costal margin .

Lycoderides burmeisteri (Fairmaire, 1846)

15'. Suprahumeral horns with borders thick, not carinate; posterior process strongly sinuate, almost curved in right angle; forewings hyaline with basal $2 / 3$ coriaceous and apical margin infuscated. (Female)

Lycoderides oliviae, sp. nov.

16. Suprahumeral horns almost horizontal, highly inflated (Figs. 21, 35) 17

16'. Suprahumeral horns triangular, V-shaped (Figs. 6, 31)

18

17. Posterior process inflated, with inferior margin close to scutellum Lycoderides brulei, sp. nov.

17'. Posterior process subcylindrical, falcate, remote from scutellum. (Male) ............... Lycoderides oliviae, sp. nov.

18. Posterior process with base located close to summit of pronotum; suprahumeral horns slightly directed anteriorly (Fig. 6) .... Lycoderides fuscus (Amyot \& Serville, 1843)

$18^{\prime}$. Posterior process with base located distant from the summit of pronotum, closerto scutellum; suprahumeral horns directed laterally (Fig. 31) ... Lycoderides meloi, sp. nov.

19. Each suprahumeral horn, viewed from above, triangular, longer than its basal width (Figs. 7, 8) 20

19'. Each suprahumeral horn, viewed from above, rounded, shorter than its basal width (Fig. 2). Lycoderides brevilobus (Sakakibara, 1972)

20. Pronotum low; posterior process with its base located close to the suprahumeral horns (Fig. 8).

Lycoderides hippocampus (Fabricius, 1803)

20'. Pronotum elevated, subcylindrical; posterior process remote from the suprahumeral horns, extended posteriorly, shaped as steps of a staircase (Fig. 7).

Lycoderides gradatus (Sakakibara, 1972)

21 .Pronotum foliaceous as a whole, without distinct posterior process (Fig. 10)

21 '. Pronotum slender, with distinct posterior process (Figs. $11,15)$ 23

22. Pronotum with dorsal outline widely arched (Fig. 10).. Lycoderides marginalis (Walker, 1851)

22 '. Pronotum with dorsal outline straightly descending posteriorly (Fig. 9) .

Lycoderides luteus (Funkhouser, 1940)

23. Anterior process shorter than posterior process; the latter sinuous above scutellum, and with its apex abruptly acuminate (Fig. 11) .... Lycoderides obtusus (Sakakibara, 1991)

23'. Anterior process longer than posterior process; the latter straight throughout, its apex gradually acuminate (Fig. 15) ............... Lycoderides protensus (Sakakibara, 1991)
Lycoderides amazonicus (Sakakibara, 1991), comb. nov. Fig. 1

Lycoderes (Lycoderides) amazonica [sic] Sakakibara, 1991: 655 (Type locality: BRASIL. Amazonas: Tabatinga).

Lycoderes (Lycoderides) amazonicus; McKamey, 1998: 307; Cryan \& Deitz, 1999: 768.

Pronotum dark castaneous; anterior process well developed, directed anterodorsally, subcylindrical, claviform, suprahumeral horns reduced, triangular; posterior process slender, base close to scutellum. Forewings castaneous, opaque. Male and female similar.

Distribution. BRAZIL (Amazonas). New record: ECUADOR (Napo. 1 \&, DZUP).

Lycoderides brevilobus (Sakakibara, 1972), comb. nov. Fig. 2

Lycoderes (Lycoderides) brevilobus Sakakibara, 1972: 102 (Type locality: BRAZIL. Guanabara [Rio de Janeiro]: Rio de Janeiro); McKamey, 1998: 307; Cryan \& Deitz, 1999: 768.

Pronotum elevated above head in a short anterior process, almost vertically; suprahumeral horns reduced, triangular; posterior process slender, with base not distant from scutellum, more or less falcate. Forewings mostly hyaline, apical margin infuscated. Male unknown.

Distribution. BRAZIL (Rio de Janeiro).

Lycoderides burmeisteri (Fairmaire, 1846), comb. nov. Fig. 3

Lycoderes burmeisteri Fairmaire, 1846: 525 (Type locality: BRAZIL). Lycoderes (Lycoderides) burmeisteri; Sakakibara, 1972: 97; McKamey, 1998: 307; Cryan \& Deitz, 1999: 768.

Pronotum dark-brown; anterior process obliquely directed anterodorsally, suprahumeral horns slender, contiguous, usually touching each other at internal midmargins; posterior process slender, straight, with base slightly remote from scutellum. Forewings opaque except for a small triangular hyaline area at costal margin. Male and female similar.

Distribution. COLOMBIA. BRAZIL (Minas Gerais, Rio de Janeiro, São Paulo, Paraná, Santa Catarina, Rio Grande do Sul).

\section{Lycoderides cultratus (Sakakibara, 1991), comb. nov.} Fig. 4

Lycoderes (Lycoderides) cultrata [sic] Sakakibara, 1991: 657 (Type locality: BRAZIL. Mato Grosso: Sinop).

Lycoderes (Lycoderides) cultratus; McKamey, 1998: 307; Cryan \& Deitz, 1999: 768

Pronotum castaneous, reddish; anterior process elongate, more or less blade-shaped, with sharp edge turned backwards, suprahumeral horns reduced to carina-like projection; pos- 
terior process straight, more or less tectiform; very close to scutellum. Forewings opaque. Female unknown.

Distribution. BRAZIL (Mato Grosso).

\section{Lycoderides fernandezi (Strümpel, 1988), comb. nov.} Fig. 5

Lycoderes fernandezi Strümpel in Strümpel \& Strümpel, 1988: 177 (Type locality: VENEZUELA. Aragua: Rancho Grande); McKamey, 1998: 304; Cryan \& Deitz, 1999: 768

Pronotum yellowish brown; anterior process slender, projected obliquely anteriorly, more or less sinuate near apex, suprahumeral horns reduced, triangular; posterior process slender, straight, entirely covering scutellum. Forewings with basal two-thirds punctate, apical third hyaline yellow. Male and female similar.

Distribution. VENEZUELA.

Lycoderides fuscus (Amyot \& Serville, 1843), comb. nov. Fig. 6

Lycoderes fuscus Amyot \& Serville, 1843: 552 (Type locality: unknown). Lycoderes (Lycoderides) fuscus; Sakakibara, 1972: 99; McKamey, 1998: 307; Cryan \& Deitz, 1999: 768.

Pronotum dark brown; anterior process more or less vertical above head, suprahumeral horns well developed, triangular, disposed in wide open V; posterior process falcate at base, remote from scutellum. Forewings infuscate at internal and apical margins, leaving a large triangular hyaline area at costal margin. Male and female similar.

Distribution. BRAZIL (Espírito Santo, Rio de Janeiro, São Paulo, Paraná).

\section{Lycoderides gradatus (Sakakibara, 1972), comb.nov.}

Fig. 7

Lycoderes (Lycoderides) gradatus Sakakibara, 1972: 101 (Type locality: BRAZIL. Mato Grosso: Utiariti); McKamey, 1998: 308; Cryan \& Deitz, 1999: 768

Pronotum dark brown; anterior process obliquely directed anterodorsally, subcylindrical, slightly constricted near apex, claviform, suprahumeral horns short, triangular, horizontal; posterior process with base remote from scutellum, largely falcate, more or less in right angle. Forewings with apical margin infuscated. Male unknown.

Distribution. BRAZIL (Pará, Mato Grosso). New record: PERU (Cuzco. 1 \&, DZUP).

\section{Lycoderides hippocampus (Fabricius, 1803), comb. nov.}

\section{Fig. 8}

Centrotus hippocampus Fabricius, 1803: 20 (Type locality: America meridionali [South America, Guiana]).

Lycoderes (Lycoderides) hippocampus; Sakakibara, 1972: 95; McKamey, 1998: 308; Cryan \& Deitz, 1999: 768
Pronotum dark brown, except basal portion of posterior process yellowish green; anterior process short, more or less vertical above head; suprahumeral horns reduced, triangular; posterior process with base remote from scutellum, falcate. Forewings hyaline, except apical margin infuscate. Male and female similar.

Distribution. COLOMBIA. ECUADOR. PERU. GUYANA. BRAZIL (Pará, Rio de Janeiro, Rio Grande do Sul).

\section{Lycoderides luteus (Funkhouser, 1940), comb. nov.}

Fig. 9

Lycoderes lutea [sic] Funkhouser, 1940: 275 (Type locality: PERU. Guaybamba).

Lycoderes luteus; Sakakibara, 1972: 134; McKamey, 1998: 305.

Lycoderes (Lycoderides) luteus: Cryan \& Deitz, 1999: 768.

Female. Pronotum yellowish castaneous, base of posterior process greenish; anterior process short, obliquely directed anterodorsally, suprahumeral horns obsolete, triangular; posterior process straight, more or less laminar, very close to scutellum. Forewings hyaline with apical margin infuscate.

Distribution. PERU. New records: COLOMBIA (Caqueta. 1 o, DZUP); FRENCH GUIANA (Formigasaria. 1 \% 1 o", DZUP); BRAZIL (Mato Grosso. 1 O", DZUP).

Funkhouser (1940) described the species based on a single female specimen from Peru. The male is described below.

Male. Head, pronotum, and legs, yellowish castaneous; posterior process with transverse greenish band near base; forewings with apical margin infuscate; abdomen yellowish green. Pronotum, in lateral view, more or less triangular, slightly inclined anteriorly, with scattered warts above metopidium, apex of anterior process rounded, suprahumeral horns obsolete; posterior process continuous with anterior process, widely arched to apex, foliaceous, base very close to scutellum. Forewings hyaline, except base punctate and apical margin infuscate. Legs with spatulate tibiae.

Remarks. This species differs from others in having the pronotum more or less foliaceous, with its base close to scutellum. It is, in some aspect, similar to the male of L. pennyi, but smaller and lighter in color. The male resembles the female in overall aspect, but has the anterior process reduced, more or less continuous with the posterior process. The female, on the other hand, has the anterior process slightly more developed and obliquely produced anterodorsally.

Lycoderides marginalis (Walker, 1851), comb. nov. Fig. 10

Membracis marginalis Walker, 1851: 479 (Type locality: BRAZIL. Pará); Broomfield, 1971: 361.

Lycoderes (Lycoderides) marginalis; Sakakibara, 1991: 652; McKamey, 1998: 308; Cryan \& Deitz, 1999: 768.

Pronotum ferrugineous, triangular, foliaceous; anterior process obliquely inclined anterodorsally, suprahumeral horns obsolete, triangular; posterior process continuous with anterior process, widely arched, foliaceous, base close to scutel- 

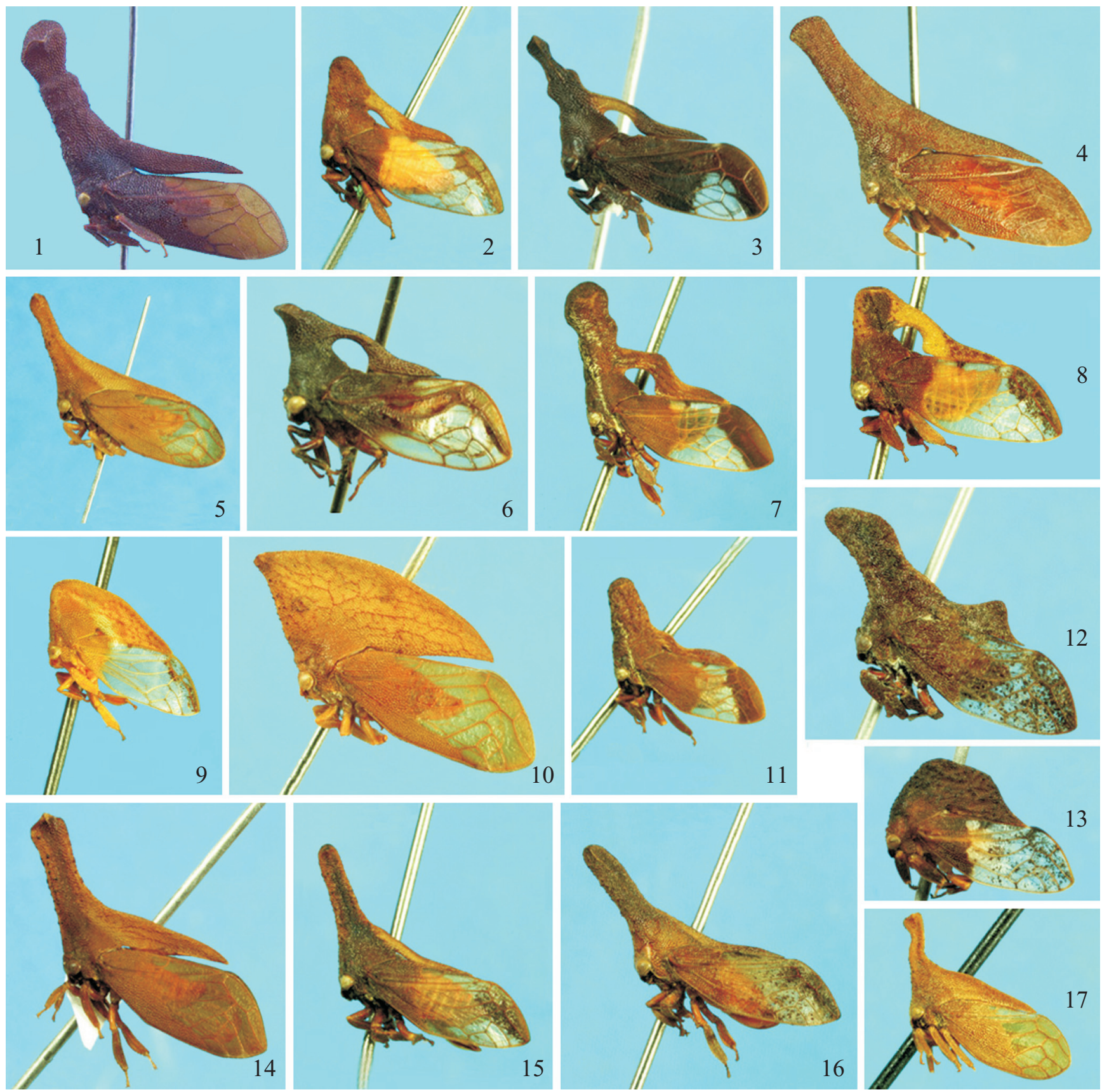

1

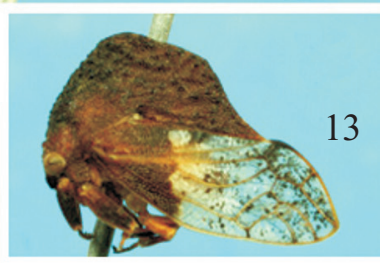

Figs. 1-17. Species of Lycoderides. 1, L. amazonicus (Sakakibara, 1991); 2, L. brevilobus (Sakakibara, 1972); 3, L. burmeisteri (Fairmaire, 1846); 4, L. cultratus (Sakakibara, 1991); 5, L. fernandezi (Strümpel, 1988); 6, L. fuscus (Amyot \& Serville, 1843); 7, L. gradatus (Sakakibara, 1972); 8, L. hippocampus (Fabricius, 1803); 9, L. luteus (Funkhouser, 1940), male; 10, L. marginalis (Walker, 1851); 11, L. Lycoderides obtusus (Sakakibara, 1991); 12-13, L. pennyi (Sakakibara, 1991), female and male, respectively; 14, L. phasianus (Fowler, 1896); 15, L. protensus (Sakakibara, 1991); 16, L. serraticornis (Fowler, 1896); 17, L. strumpeli (Sakakibara, 1991).

lum, provided with scattered warts on metopidium and netlike smooth lines on posterior process. Forewings fuscous, translucent. Male and female similar.

Distribution. BRAZIL (Pará). New record: BRAZIL (Mato Grosso. 1 Q, DZUP).

Remarks. The general aspect of the foliaceous pronotum resembles a species of Stegaspis. Broomfield (1971) pointed out that the holotype, in the British Museum, is a male specimen and not female as stated in Walker's (1851) description.

\section{Lycoderides nathanieli (Cryan, 1999), comb. nov.}

Lycoderes (Lycoderides) nathanieli Cryan in Cryan \& Deitz, 1999: 764 (Type locality ECUADOR. Napo: Sierrazul).

No specimen of this species was examined. The diagnostic characters and comments are transcribed below from Cryan \& Deitz (1999).

Female. "Lycoderides nathanieli has enlarged suprahumeral horns extending anteriorly and curving toward the mid- 
line; the elevated posterior pronotal process bears two small pyramiform 'horns' apically.

The pronotal structure of $L$. nathanieli is unusual in that the metopidium and posterior pronotal process are similar to those of other Lycoderes (and even Stegaspis) species, but the suprahumeral horns are reminiscent of those of Oeda informis and $O$. hamulata, albeit much more produced. Unlike most other species of Lycoderes, the metathoracic tibiae of $L$. nathanieli bear reduced cucullate setae in the distal halves of setal row II and III."

Distribution. ECUADOR.

\section{Lycoderides obtusus (Sakakibara, 1991), comb.nov.} Fig. 11

Lycoderes (Lycoderides) obtusa [sic] Sakakibara, 1991: 657 (Type locality: BRAZIL. Mato Grosso: Sinop).

Lycoderes (Lycoderides) obtusus; McKamey, 1998: 308; Cryan \& Deitz, 1999: 768.

Pronotum dark brown; anterior process obliquely directed anterodorsally, subcylindrical, suprahumeral horns small, triangular; posterior process slender, slightly sinuous, base close to scutellum. Forewings with a transversal hyaline band. Male and female similar, the former with the anterior process slightly shorter.

$$
\text { Distribution. BRAZIL (Mato Grosso). }
$$

Lycoderides pennyi (Sakakibara, 1991), comb. nov. Figs. 12, 13

Lycoderes (Lycoderides) pennyi Sakakibara, 1991: 653 (Type locality: BRAZIL. Amazonas: Itacoatiara); McKamey, 1998: 308; Cryan \& Deitz, 1999: 768.

Pronotum dull brown, scattered with small warts; forewings hyaline speckled with dark brown, more intensely towards apex. Female: anterior process long, strong, more or less laminar, with tip slightly curved anterodorsally, suprahumeral horns obsolete, disposed laterally and preapically; posterior process slender, laminar, slightly elevated before apex, base close to scutellum. Male: pronotum laterally compressed, in lateral view, rounded on top above scutellum, in a humplike elevation; anterior and posterior processes indistinct, suprahumeral horns reduced to small wartlike protuberances.

Distribution. BRAZIL (Amazonas). New records: FRENCH GUIANA (Montagne des Chevaux. 1 \& 1 O', DZUP); BRAZIL (Rondônia. 1 q, DZUP).

\section{Lycoderides phasianus (Fowler, 1896), comb. nov.} Fig. 14

Lycoderes phasianus Fowler, 1896: 164 (Type locality: PANAMA. Bugaba); Broomfield, 1971: 368 (lectotype, female); Sakakibara, 1972: 133; McKamey, 1998: 305.

Enchenopa minamen Buckton, 1901 in Buckton, 1903: 51 (Type locality.: ECUADOR. Cachabe); Broomfield, 1971: 361 (lectotype, male). Syn. nov.
Lycoderes minamen; Sakakibara, 1972: 133; McKamey, 1998: 305; Cryan \& Deitz, 1999: 768.

Lycoderes (Lycoderes) minamen: Cryan \& Deitz, 1999: 768.

Pronotum dark brown; anterior process long, laterally compressed, obliquely directed anterodorsally, suprahumeral horns apical, small, triangular; posterior process acuminate, straight, base covering scutellum. Forewings opaque. Male and female similar.

Remarks. Cryan \& Deitz (1999) placed Lycoderes minamen (Buckton) in the subgenus L. (Lycoderes). A photograph of the lectotype (in BMNH The Natural History Museum, London, UK) shows, however, that the forewing venation is that of Lycoderides. Furthermore a comparison of this photograph to one of the lectotype of L. phasianus Fowler (BMNH) indicates the former is a junior synonym of the latter.

Distribution. MEXICO. HONDURAS. PANAMÁ. ECUADOR. New record: PERU (Genaro Herrera. 1 \&, DZUP).

Lycoderides protensus (Sakakibara, 1991), comb. nov. Fig. 15

Lycoderes (Lycoderides) protensa [sic] Sakakibara, 1991: 659 (Type locality: BRAZIL. Mato Grosso: Sinop).

Lycoderes (Lycoderides) protensus; McKamey, 1998: 308; Cryan \& Deitz, 1999: 768 .

Pronotum dark brown; anterior process slightly compressed laterally, oblique, little longer than posterior process, suprahumeral horns small, triangular; posterior process slender, styliform, base close to scutellum. Forewings infuscated at apical margin. Male unknown.

Distribution. BRAZIL (Mato Grosso).

Lycoderides serraticornis (Fowler, 1896), comb. nov. Fig. 16

Lycoderes serraticornis Fowler, 1896: 165 (Type locality: PANAMA. Volcan de Chiriqui); Broomfield, 1971: 375 (lectotype, female); Sakakibara, 1972: 133; McKamey, 1998: 305; Cryan \& Deitz, 1999: 768.

Pronotum dull brown; anterior process long, about as long as posterior process, subcylindrical, oblique, scattered with small warts, suprahumeral horns obsolete, triangular; posterior process slender, styliform, base covering scutellum. Forewings hyaline speckled with brown, more densely speckled towards apex. Male unknown.

Distribution. PANAMA. ECUADOR. COLOMBIA. GUYANA. PERU. New record: COSTA RICA (Turrialba. 3 우 1 O", DZUP).

Lycoderides strumpeli (Sakakibara, 1991), comb. nov. Fig. 17

Lycoderes (Lycoderides) strumpeli Sakakibara, 1991: 653 (Type locality: VENEZUELA. Miranda: Alpes del Tuy); McKamey, 1998: 308; Cryan \& Deitz, 1999: 768 . 
Pronotum yellowish castaneous; anterior process shorter than posterior process, slightly compressed, more or less sinuous (like an elephant's trunk), suprahumeral horns obsolete, triangular; posterior process acuminate, covering scutellum. Forewings translucent yellow. Male and female similar.

\section{Distribution. VENEZUELA.}

\section{Lycoderides abditus, sp. nov.}

Figs. 18, 19

Diagnosis. Dull castaneous; forewing with apical half speckled with dark castaneous. Pronotum elevate above head, anterior process having on summit, at each side of median carina, two small suprahumeral horns; dorsum of posterior process scattered with small warts, in lateral view, strongly descending to apex, slender especially at middle, extended to apex of clavus; scutellum completely covered.

Description. Male. Head castaneous; pronotum dull castaneous, slightly darker on metopidium; forewing castaneous at basal half, with transverse brownish band from costal margin to clavus, apical half transparent, finely speckled with brown. Legs brownish, with apex of tibiae and tarsi, clear castaneous. Head twice as wide as long, deflexed; eyes hemispheric; ocelli conspicuous, located above transocular line, equidistant to each other and to eyes, and closer to superior margin of head; postclypeus as wide as long, slightly trilobate apically, extended little beyond margins of vertex. Pronotum roughly punctured, covered with short and decumbent hairs, and scattered with wartlike small protuberances; in frontal view, more or less tectiform, elevated above head for about width of head; anterior process truncate at summit, having at each side small suprahumeral horn; in lateral view, slightly projected anteriorly; posterior process horizontal above humeral angles and then strongly descending to near claval margin, extending parallel to it until apex, slender at base, tectiform, and slightly elevate preapically, covering scutellum completely. Forewings punctate at basal half, similarly as pronotum, and other half transparent, and entirely speckled. Legs with tibiae spatulate; pro- and mesothoracic tibiae without cucullate setae, metathoracic tibiae with cucullate setae in row II.

Female. Unknown.

Measurements (mm). Male: total length 6.60; length of pronotum 4.50; width of head 1.80; length of head 1.08; length of forewing 5.80 .

Holotype, male, "GUYANE FRANÇAISE $\mid$ Itoupé - DZ 570m | N $03^{0}$ $01^{\prime}$ W $053^{0} 05^{\prime} \mid 24 / 05 / 2010$ | (vitre) - S.E.A.G.”. (MNHN).

Remarks. This species resembles $L$. serraticornis Fowler, but differs in having the pronotum more or less triangular, in lateral view, without frontal process. Lycoderides abditus sp. nov. also has small warts scattered mainly on metopidium principally; suprahumeral horns very small, similar to warts. The posterior process is slender, tectiform, and slightly elevated before apex. The scutellum is concealed. This last character inspired the specific name: abditus, a Latin word meaning "covered, or concealed".

\section{Lycoderides brulei, sp. nov.}

Figs. 20-25

Diagnosis. Female: dull castaneous. Pronotum highly elevated above head, laterally expanded at apex in two large, inflated, triangular suprahumeral horns; posterior process close to scutellum, wide at base, more or less compressed, dorsally at same level as suprahumeral horns, then descending almost vertically and terminating in a short, horizontal, triangular apex, before internal angle of forewings. Forewings with large translucent triangular area on costal margin. Legs with apex of tibiae and tarsi whitish. Abdomen whitish. Male: brown; pronotum similar to female's, but apical lobes smaller. Forewings transparent, basal third opaque, and apical margins infuscate.

Description. Female. Head castaneous; pronotum dull castaneous, covered with short and decumbent white hairs. Forewings opaque, dull castaneous, with large translucent triangular area, with its base on costal margin and vertex almost attaining mid claval suture. Legs castaneous, pro- and mesothoracic tibiae with base whitish; metathoracic tibiae with apical third whitish; all tarsi whitish. Head twice wider than long; eyes small, hemispheric; ocelli located above transocular line, closer to eyes and superior margin of head than to each other; postclypeus deflexed, triangular, slightly longer than wide, apex trilobate, extended slightly beyond margins of vertex. Pronotum roughly punctured, surface with smooth elevated lines forming netlike structures; median carina percurrent, sharp from top of metopidium to apex of posterior process. In frontal view, anterior process highly elevated above head, constricted at top of metopidium, and then gradually expanded laterally in two horizontal suprahumeral horns, with tips acute and slightly decurved, with distance between extremities about twice the distance between humeri; anterior margins of horns carinate from tip to near median carina. In superior view, each apical lobe in form of equilateral triangle, space between both concave; posterior margins carinate. In lateral view, above metopidium, slightly projected anteriorly; posterior process enlarged basally, more or less compressed but also slightly inflated at middle; inferior margin close to scutellum and forewings; superior margin at the same level as suprahumeral horns, more or less horizontal and then descending almost vertically and terminating in acute point just before claval apex. Forewings obliquely truncate at apex, with external angle acute, tip rounded; one discoidal and five apical cells, these obliquely disposed; fourth apical cell triangular, distinctly petiolate, with longest dimension parallel to apical margin; third and fifth apical cells contiguous having petiole of fourth apical cell as a common side; with one $r-m$ and one $m-c u$ crossveins. Legs with tibiae spatulate; pro- and mesothoracic tibiae without cucullate setae, metathoracic tibiae with $\mathrm{cu}-$ cullate setae in row II. 
Male. Similar to female; color light brown, forewings almost entirely hyaline, except base brown and punctate, and narrow infuscate band along apical margin. Pronotum with suprahumeral horns smaller and convex dorsally between them.

Measurements (mm). Female/male: total length 8.60/7.20; length of pronotum $6.00 / 5.00$; width of head 2.30/2.10; length of forewing 6.70/6.30.

Holotype, female, "GUYANE FRANÇAISE | Laussat (Ouest) | PLP3- Sable Blanc | 12/9/2010 - Lamarre leg." DZUP. Paratypes: 5 females, with same label data as holotype (2 in MNHN, 3 in DZUP); 1 female and 1 male, "GUYANE FRANÇAISE | Pilon Rocheux | 24/03/2009 | (lumineux) - S.E.A.G." (MNHN); 1 male, with same label data as holotype (DZUP). Four specimens (1 male and 3 females, DZUP) missing upper portion of pronotum, were not included in the type series.

Remarks. This species strongly resembles Lycoderes mitratus Germar, 1835, in having the pronotum strongly elevated above the head and dorsally with two large diverging triangular suprahumeral horns; these horns, however, are not as large as in L. mitratus. The coloration is also identical including the forewings with a translucent triangular area.

The specimens of Lycoderides brulei sp. nov. examined were collected via light-trapping, stored in envelopes, and subsequently mounted on pins. Most specimens were found with part of the pronotum broken off, all having the fracture at exactly in the same place, just above the metopidium, where the anteroposterior process begins (Fig. 24). For several it was possible to glue the separate portions to the respective individuals, perhaps of course, without $100 \%$ accuracy (the coloration helped in this effort).

Mann (1912) noted that individuals of Combophora beski easily lose the inflated portion of the pronotum, flying away as if nothing has happened. He concluded that this "may be considered as a sort of adaptive self mutilation, or autotomy".

In L. brulei, close examination reveals a thin line around the "neck", corresponding to the line of weakness (Fig. 25), or "ligne de pré-cassure" observed by Boulard (1983) in Anchistrotus amitteraglobus. According to Boulard (op. cit.), this line of weakness permits an accidental fracture (cassure accidentelle), due to any physical action on the pronotum, and not by self mutilation or autotomy. Lycoderides brulei sp. nov. also likely makes use of the same device either to escape a predator rapidly or for reasons not yet known.

The name of the new species is in honor of Stèphane Brule (Société Entomologique Antilles-Guyane (SEAG), French Guiana).

\section{Lycoderides capixaba, sp. nov.}

Figs. 26, 27

Diagnosis. Dull castaneous, with basal half of posterior process greenish yellow; forewings with apical half speckled with dark castaneous. Pronotum more or less foliaceous, elevated vertically above head, then curving gradually to apex; metopidium provided with scattered warts; without suprahumeral horns; scutellum only visible laterally.
Description. Male. Head castaneous; pronotum dull castaneous, with posterior process greenish yellow at basal 2/ 3 , apex castaneous; forewings coriaceous and castaneous basally, remainder hyaline speckled with dark castaneous; legs castaneous; abdomen orangish. Head twice as wide as long, deflexed; eyes hemispheric; ocelli conspicuous, located above transocular line, slightly closer to eyes and superior margin than to each other; postclypeus as wide as long, extended slightly beyond margins of vertex. Pronotum roughly punctured, covered with short and decumbent hairs, and scattered with wartlike small protuberances; in frontal view, more or less tectiform, elevated above head for about width of head, sharp at summit, having no suprahumeral horns; in lateral view, more or less triangular, without distinct anterior process, metopidium vertical, roundly curved posteriorly, dorsum widely arched to apex; posterior process very close to scutellum, this visible only laterally. Forewings punctate in basal third (punctuation similar to pronotum), and remainder transparent, and speckled, especially towards apex. Legs with tibiae spatulate; pro- and mesothoracic tibiae without cucullate setae, metathoracic tibiae with cucullate setae in row II.

Female. Unknown.

Measurements (mm). Male: total length 5.20; length of pronotum 3.80; width of head 1.50; length of forewings 4.10 .

Holotype, male. "BRASIL. Espirito Santo: | Linhares. IX-1972 | M. Alvarenga leg." (DZUP). Paratype, male: "Pedro Canário, Espírito Santo | Conceição da Barra | Brasil - X-1972 |M. Alvarenga leg.” (DZUP).

Remarks. Lycoderides capixaba sp. nov. is described from two male specimens. It resembles the male of Lycoderides pennyi in having the pronotum more or less foliaceous, without defined anterior and posterior processes. Lycoderides capixaba is smaller and somewhat yellowish green; in lateral view, the pronotum is vertically elevated above the head, and lacks suprahumeral horns; in L. pennyi it is clearly reclined, more or less horizontal, and then abruptly descending to apex; suprahumeral horns obsolete but distinguishable. The color is uniformly dark brown.

The name capixaba, from Tupi, is a nickname usually given to those native to the state of Espírito Santo.

\section{Lycoderides cavichiolii, sp. nov.}

Figs. 28, 29

Diagnosis. Male: dark castaneous to almost black; forewings yellow amber, translucent; abdomen orangish. Pronotum highly elevated above head, having on top slender suprahumeral horns disposed in V; posterior process falciform, distant from scutellum, its base near to base of suprahumeral horns, distal half tectiform, close to anal margins of forewings, apex acute terminating at claval apex.

Description. Male. Head and pronotum dark castaneous, almost black, covered with short and decumbent white hairs; suprantennal ledges castaneous; posterior process castaneous, with diffuse yellowish areas; underside of thorax dark 

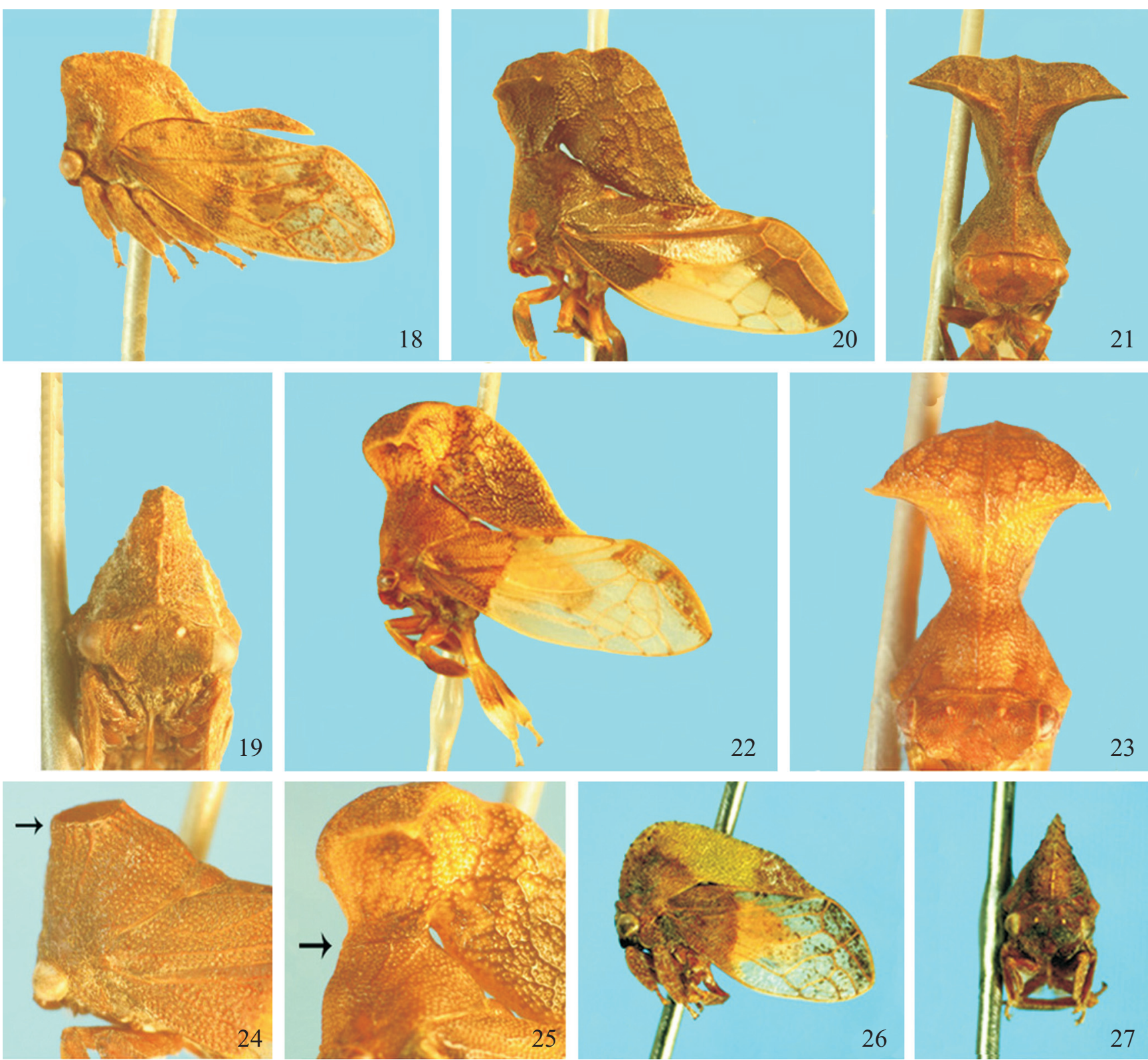

Figs. 18-27. New species of Lycoderides. 18-19, L. abditus sp. nov. (holotype, male); 20-25, L. brulei sp. nov.: 20-21 (holotype, female); 22-23 (paratype, male; 24-25 details of pronotum with indication (arrow) of line of weakness; 26-27, L. capixaba sp. nov. (holotype, male).

castaneous; legs castaneous; forewings yellow-amber, translucent; abdomen orangish. Head slightly wider than long; vertex little sculptured, superior margin well arched, with small protuberance above each ocellus, suprantennal ledges foliaceous, slightly produced; eyes small, hemispheric; ocelli located above transocular line, closer to eyes and superior margin of head than to each other; postclypeus deflexed, triangular, slightly longer than wide, apex trilobate, extended slightly beyond margins of vertex. Pronotum rough and uniformly punctured; median carina sharp from between suprahumeral horns to apex of posterior process. In frontal view, highly elevated above head to about twice width of head and having slender suprahumeral horns dorsally disposed in a great $\mathrm{V}$, each arm acute at apex, subfoliaceous, anterior and posterior margins sharp, laterally carinate; in lateral view, metopidium slightly inclined anteriorly; posterior process relatively slender, initiating at base of suprahumeral horns, widely arched above scutellum, reaching internal margins of forewings, running close to them until apex of clavus; this portion slightly enlarged and tectiform, with acute apex. Forewings with apical margins rounded; one discoidal and five apical cells; fourth apical cell triangular, distinctly petiolate; third and fifth apical cells contiguous having the petiole of fourth apical cell as a common side; with one $r-m$ and one $m-c u$ crossveins. Legs with tibiae spatulate; pro- and mesothoracic tibiae without cucullate setae, metathoracic tibiae with cucullate setae in row II.

Female. Unknown. 
Measurements (mm). Male: total length 8.00; length of pronotum 5.80; width of head 1.60; length of forewing 5.50.

Holotype, male, "RJ, Brasil, P[arque]. N[acional]. Itatiaia | Maromba | 22.431 ${ }^{\circ} \mathrm{S} 44.625^{\circ} \mathrm{W} \mid$ 30.X.2011 1200m | R.R. Cavichioli leg." (DZUP). Paratype, male, with same label data (DZUP).

Remarks. Lycoderides cavichiolii sp. nov. resembles Lycoderes ancora (Germar, 1835) in having the pronotum with suprahumeral horns $\mathrm{V}$-shaped and the posterior process falciform. The forewings, however, have the $r-m$ crossvein basad to the ramification of vein $\mathrm{M}$, characteristic of Lycoderides.

The species is named after Rodney R. Cavichioli, an entomological colleague with many contributions on the taxonomy of leafhoppers (Auchenorrhyncha, Cicadellidae).

\section{Lycoderides meloi, sp. nov.}

Figs. 30, 31

Diagnosis. Male: entirely dull castaneous, except forewings with large transparent area at middle, and abdomen yellow. Pronotum highly elevated above head, laterally expanded at apex in two short triangular suprahumeral horns; posterior process slender and straight, just emarginate above scutellum, with base distant from base of suprahumeral horns.

Description. Male. Head, pronotum, underside of thorax, and legs, dull castaneous, covered with short and decumbent white hairs; forewings dull castaneous, except large central area hyaline; abdomen yellow. Head twice wider than long, superior margin well arched; eyes small, hemispheric; ocelli located above transocular line, closer to eyes and superior margin of head than to each other; postclypeus deflexed, triangular, slightly longer than wide, apex trilobate, extended slightly beyond margins of vertex. Pronotum densely and uniformly punctured; median carina percurrent, weak on metopidium and well marked from between suprahumeral horns to apex of posterior process. In frontal view, highly elevated above head, gradually acuminate, and suddenly bifurcated in wide V-shaped suprahumeral horns, relatively short, about as long as wide at base, tricarinate, with tips acute. In lateral view, above metopidium, slightly projected anteriorly; posterior process slender, straight, with base near to scutellum, emarginate above it, distant from suprahumeral horns, distal half more or less compressed, tectiform, and terminating in acute point at claval apex. Forewings obliquely truncate at apex, with external angle acute, tip rounded; one discoidal and five apical cells, these obliquely disposed; fourth apical cell triangular, distinctly petiolate, with longest dimension parallel to apical margin; third and fifth apical cells contiguous having petiole of fourth apical cell as common side; with one $r-m$ and one $m-c u$ crossveins. Legs with tibiae spatulate; pro- and mesothoracic tibiae without cucullate setae, metathoracic tibiae with cucullate setae in row II.

Female. Unknown.

Measurements (mm). Male: total length 5.50; length of pronotum 5.60; width of head 1.30; length of forewing 5.00.
Holotype, male, "Brasil, BA, 8 Km NW | Camacã, Serra Bonita, | $15.390^{\circ} \mathrm{S}-39.564^{\circ} \mathrm{W}$, | 800m, 21.i.2011, G. Melo, | em armadilha luminosa" (DZUP).

Remarks. Lycoderides meloi sp. nov. resembles, at first sight, Lycoderides burmeisteri (A. \& S.) in having the pronotum directed anterodorsally in a slender, porrect process with short suprahumeral processes apically; these, however, in the new species, are divergent, in a wide $\mathrm{V}$, instead of contiguous as in L. burmeisteri.

The species name is dedicated to Gabriel A. R. Melo, an entomological colleague with many publications on the systematics of bees (Hymenoptera, Apoidea).

\section{Lycoderides oliviae, sp. nov.}

Figs. 32-35

Diagnosis. Dark castaneous, irregularly maculate with yellowish brown; forewings with middle third hyaline. Highly dimorphic species. Female: pronotum elevated above head, in lateral view, curved anteriorly; suprahumeral horns elongated, contiguous, apices divergent; posterior process arched above scutellum, slender at base and horizontal, abruptly bent almost vertically, thicker than anterior portion, then parallel to internal margin of forewing, ending in an acute point before claval apex. Male: pronotum relatively low, strongly inflated above metopidium; suprahumeral horns subtriangular, inflated, disposed almost horizontally with apices slightly directed ventrally, with margins thick, not carinate; posterior process arched above scutellum, thick at base, gradually curved and acuminate, not attaining claval apex.

Description. Female. Head castaneous; pronotum covered with short and decumbent white hairs, not uniformly dark castaneous: shoulders brownish, base of posterior process yellowish. Forewings with basal third punctate, dark castaneous maculate with yellowish brown; middle third hyaline, and apical third infuscate but with some small areas hyaline. Legs castaneous, tibiae slightly yellowish to apex.

Head more than twice wider than long; eyes hemispheric, almost pedunculate; ocelli conspicuous, located above transocular line, closer to eyes and superior margin of head than to each other; postclypeus deflexed, triangular, slightly longer than wide, apex trilobate, extended slightly beyond margins of vertex. Pronotum densely punctate; in lateral view, with anterior process well developed, obliquely directed anterodorsally from top of metopidium, gradually tapered to apex, bearing evident elevated smooth line from tip of suprahumeral horns to near humeral angles; in frontal view, anterior process about two times longer than width of head, suprahumeral horns elongate, contiguous, more or less inflated, margins rounded, not carinate, almost touching each other at middle, apices divergent; posterior process sinuous, its base located between suprahumeral horns and scutellum, slender and horizontal, then bent almost in right angle, thick, subcylindrical, acuminate and ending in acute point before claval apex. Forewings obliquely truncate at apex, with external angle acute, tip rounded; one discoidal and five apical 

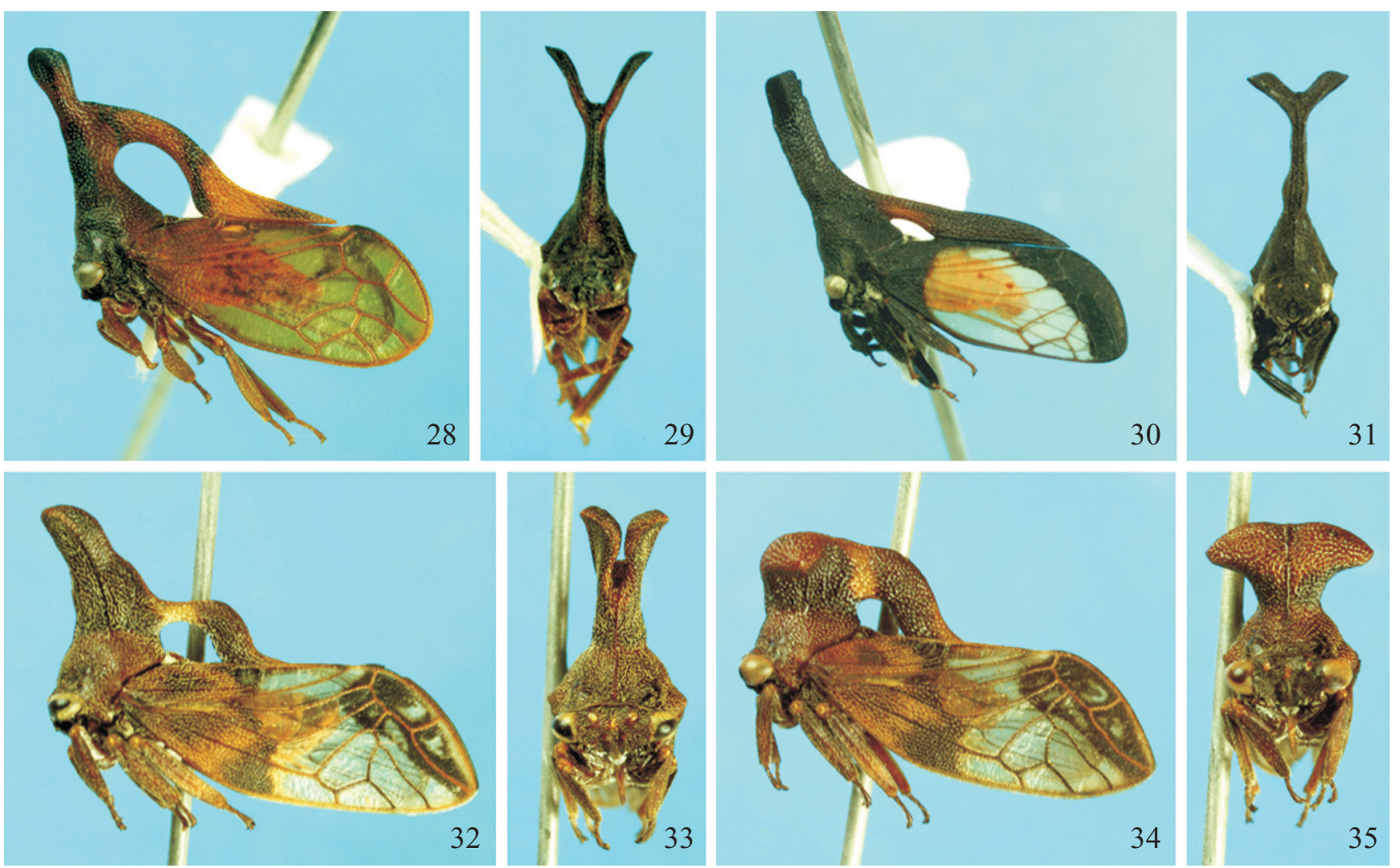

Figs. 28-35. New species of Lycoderides. 28-29, L. cavichiolii sp. nov. (holotype, male); 30-31, L. meloi sp. nov. (holotype, male); 32-33 and 34-35, L. oliviae sp. nov., (holotype, female and paratype, male, respectively).

cells, these obliquely disposed; fourth apical cell triangular, distinctly petiolate, with longest dimension parallel to apical margin; with one $r-m$, located basad to bifurcation of $\mathrm{M}$, and one $m-c u$ crossveins. Legs with tibiae spatulate; pro- and mesothoracic tibiae without cucullate setae, metathoracic tibiae with cucullate setae in row II.

Male. Slightly smaller than female; general color castaneous with dark brown on head and metopidium, inferior part of suprahumeral horns, posterior process, base of forewings. Head relatively well sculptured; eyes and ocelli conspicuous, protruded. Pronotum low, more or less inflated; anterior process, in frontal view, strongly inflated above metopidium, with suprahumeral horns directed laterally forming together a mushroomlike process; in lateral view, anterior process relatively low, little constricted above metopidium, and dilated dorsally; posterior process thick at base, at the same level as suprahumeral horns, more or less cylindrical, arched above scutellum, gradually tapered to apex.

Measurements (mm). Female/male: total length 9.60/8.00; length of pronotum 5.50/4.40; width of head 2.30/2.20; length of forewing 7.70/6.60.

Holotype, female, "BRASIL. Minas Gerais: | Berizal. Fazenda Veredão | 850m, à luz, 14/XII/2007 | Grossi, Rafael \& Parizotto" (DZUP). Paratypes: 2 females and 7 males, with same label data as holotype (DZUP).
Remarks. This species differs greatly from the others. The sexual dimorphism is remarkable. The female has the anterior process elevated and curved anteriorly, with the suprahumeral horns elongate and contiguous, similar to those of L. burmeisteri, but slightly more inflated, without evident carina at its margins; the posterior process is slender and strongly bent in the form of a stair step. The male, on the other hand, has the anterior process low, greatly inflated above metopidium, with the suprahumeral horns triangular and thick, forming together, in frontal view, a mushroomlike process; posterior process is thick basally, subcylindrical, and sinuous above the scutellum.

The species is dedicated to Olivia Evangelista, a colleague and membracidologist.

\section{Nomenclatural note}

\section{Stegaspis bracteata (Fabricius, 1787)}

Membracis bracteata Fabricius, 1787: 263 (Type locality: Cajennae [French Guyana]).

Lycoderes capitata [sic] Buckton, 1903: 203 (Type locality: unknown). Syn. nov.

Lycoderes capitatus; Sakakibara, 1972: 134; McKamey, 1998: 304.

Stegaspis viridis Funkhouser, 1915: 104 (Type locality: TRINIDAD. Port of Spain); Sakakibara, 1991: 652 (syn.); McKamey, 1998: 309.

Lycoderes viridis Strümpel, 1988: 148 (Type locality: VENEZUELA. Aragua: Rancho Grande); Sakakibara, 1991: 652 (syn.); McKamey, 1998: 309. 
Remarks. Buckton's (1903) description of Lycoderes capitata indicates that this species differs from other species of Lycoderes, and also based on the respective drawings is a synonym of Stegaspis bracteata (Fabricius). When proposing the division of Lycoderes into two subgenera, Sakakibara (1972) had no material on hand, and thus did not assign $L$. capitata to a subgenus; similarly, McKamey (1998) did not assign $L$. capitata to a subgenus in his catalogue.

\section{REFERENCES}

Amyot, C.J.-B. \& J.G. A-Serville, J.G. 1843. Histoire Naturelle des Insectes - Hémiptères. Paris, Librairie Encyclopédique de Roret, 533-553p.

Boulard, M. 1983. Sur deux Anchistrotus et la mutilation naturelle du pronotum chez les Membracides de ce genre (Homoptera). Bulletin de la Société Entomologique de France 88: 274-283.

Broomfield, P.S. 1971. A catalogue of the membracid types (Homoptera: Membracidae) in the British Museum (Natural History). Bulletin of the British Museum (Natural History), Entomology 25: 327-386.

Buckton, G.B. [1901-1902] 1903. A monograph of the Membracidae. London. L. Reeve \& Company, London. xi-293 p.

Cryan, J.R. \& Deitz, L.L. 1999. Review of the New World treehopper tribe Stegaspidini (Hemiptera: Membracidae: Stegaspidinae): II: Lycoderes Germar, Oeda Amyot \& Serville, and Stegaspis Germar. Proceedings of the Entomological Society of Washington 101: 760-778.

Fabricius, J.C. 1803. Systema Rhyngotorum: secundum ordines, genera, species adiectis synonymis, locis, observationibus, descriptionibus. Brunsvigae, C. Reichard, 314 p.

Fairmaire, L.M.H. 1846. Revue de la tribu des Membracides. Annales de la Société Entomologique de France 4: 235-320; 479-531.

Fowler, W.W. 1896. Order Rhynchota. Suborder Hemiptera-Homoptera. (Cont.). Biologia Centrali-Americana 2: 161-168.

Funkhouser, W.D. 1915. A new membracid from Trinidad. Bulletin of the Brooklyn Entomological Society 10: 103-105.

Funkhouser, W.D. 1940. New Peruvian Membracidae (Homoptera). Journal of the New York Entomological Society 48: 275-293.

Mann, W.M. 1912. A protective adaptation in a Brazilian membracid. Psyche 19: 145-147.

McKamey, S.H. 1998. Taxonomic catalogue of the Membracoidea (exclusive of leafhoppers): second supplement to fascicle I Membracidae of the General Catalogue of the Hemiptera. Memoirs of the American Entomological Institute 60: 1-377.

Sakakibara, A.M. 1972. Revisão do gênero Lycoderes Germar, 1835 (Homoptera,Membracidae). Boletim da Universidade Federal do Paraná 5: 77-138.

Sakakibara, A.M. 1991. Sobre os gêneros Stegaspis e Lycoderes: notas taxonômicas e descrição de espécies novas (Homoptera, Membracidae). Revista Brasileira de Biologia 51: 651-662.

Strümpel, H. \& Strümpel, R. 1988. Die Membraciden des Wolkenwaldes von "Rancho Grande" (Venezolannische Küstenkordillere). Teil I: Unterfamilien Centrotinae, Hoplophorioninae (Homoptera, Membracidae). Entomologische Mitteilungen aus dem Zoologischen Museum Hamburg 9: 169-192.

Walker, F. 1851. List of specimens of Homopterous insects in the collection of the British Museum 2: 261-636.

Received 26 April 2013; accepted 8 July 2013

Associate Editor: Daniela M. Takiya 